Jurnal Indonesia Sosial Teknologi: p-ISSN: 2723 - 6609

e-ISSN : 2745-5254

Vol. 2, No. 9 September 2021

\title{
PENILAIAN HARGA WAJAR SAHAM PADA EMITEN YANG TERDAFTAR DI INDEKS LQ45 PERIODE 2017 - 2019
}

Gideon Toman $^{1}$ Sri Muljaningsih ${ }^{2}$ Kiki Asmara ${ }^{3}$

Ekonomi Pembangunan/FEB/UPN "Veteran" Jatim 1,2,3

Email: gideonalfrendo7@gmail.com ${ }^{1}$

\begin{abstract}
Abstrak
Jumlah investor saham yang meningkat jumlahnya dari tahun ke tahun tentunya merupakan hal yang bagus bagi pasar modal Indonesia. kenaikan jumlah investor ini tentunya harus di imbangi dengan pengetahuan yang baik agar dapat meminimalisir risiko kerugian dalam berinvestasi di saham. Salah satunya adalah dengan mengetahui nilai wajar suatu saham. Adapun yang menjadi tujuan dalam penelitian ini adalah untuk mengetahui nilai wajar emiten yang masuk di Indeks LQ45 periode 2017 - 2019 yang telah di hitung dengan menggunakan Dividend Discount Model (DDM), Price Earning Ratio (PER), \& Price to Book Value (PBV) berada dalam kondisi murah, mahal, atau wajar serta pengambilan keputusan yang tepat sesuai dengan pedoman penilaian saham. Penelitian ini menggunakan metode deskriptif dengan pendekatan kuantitatif serta pegujian akurasi dengan Root Mean Square Error (RMSE). Kesimpulan dari penelitian ini adalah pengambilan keputusan investasi yang tepat dengan membeli saham - saham emiten berikut, diantaranya ADRO, BBNI, BBTN, BMRI, ICBP, INDF, PTPP, SMGR, WIKA, \& WSKT. Hal ini dikarenakan 10 saham perusahaan tersebut rata - rata harganya di nilai undervalued atau murah dan DDM menjadi metode penilaian harga yang paling akurat karena memiliki rata - rata nilai RMSE terkecil.
\end{abstract}

Kata kunci: Pedoman Penilaian Saham, Root Mean Square Error, Dividend Discount Model, Price Earning Ratio, dan Price to Book Value.

\section{Abstract}

The increasing number of stock investors from year to year is certainly a good thing for the Indonesian capital market. This increase in the number of investors must of course be balanced with good knowledge in order to minimize the risk of loss in investing in stocks. One of them is to know the fair value of a stock. As for the purpose of this study was to determine the fair value of issuers included in the LQ45 index for the 2017 - 2019 period which has been calculated using Dividend Discount Model (DDM), Price Earning Ratio (PER), \& Price to Book Value (PBV) are in undervalued, overvalued, or fair value conditions and make the right decisions in accordance with the guidelines stock valuations. This study uses a descriptive method with a quantitive approach as well as testing accuracy with Root Mean Square Error (RMSE). The conclusion of this research is that making the right invesment decisions by buying shares of the following issuers, including ADRO, BBNI, BBTN, BMRI, ICBP, INDF, PTPP, SMGR, WIKA, \& WSKT. This is because 
the 10 shares of the company have an average price of undervalued or cheap and DDM is the most accurate method of price assessment because it has the smallest average RMSE value.

Keywords: Stock Valuation Guidelines, Root Mean Square Error, Dividend Discount Model, Price Earning Ratio, and Price to Book Value.

\section{Pendahuluan}

Pasar modal menjadi tempat yang tepat untuk terjadinya proses antara permintaan dengan penawaran surat beharga. Dimana secara perseorangan, organisasi, ataupun badan usaha yang menempatkan dananya terhadap suatu aset, yaitu surat berharga ke perusahaan yang sedang membutuhkan dana, dengan tujuan dana tersebut nantinya digunakan untuk memperkuat modal perusahaan, melakukan ekspansi bisnis, membayar hutang, dan lain - lain. Kegiatan investasi sangat erat kaitannya dengan pasar modal, Investasi sendiri menurut (Tandelilin, 2017) merupakan komitmen atas sejumlah dana atau sumber daya lainnya yang dilakukan pada saat ini, dengan tujuan memperoleh sejumlah keuntungan di masa yang akan datang. Secara umum investasi sendiri terbagi menjadi 2 jenis yaitu investasi aset yang berwujud berupa emas, tanah, rumah atau bangunan dan investasi aset finansial yaitu penempatan aset pada produk - produk yang ada di perbankan dan pasar modal seperti saham, reksadana, etf, deposito, obligasi, dan lain - lain. Dari berbagai instrumen yang ada di pasar modal, Saham menjadi salah satu yang banyak digemari dan menarik karena memiliki return yang tinggi (high gain), tingkat return yang tinggi tersebut juga seimbang dengan tingkat resikonya yang tinggi juga (high risk).

Dalam berinvestasi saham tentunya investor mengharapkan dapat membeli saham di harga dan waktu yang tepat agar memperoleh keuntungan yang maksimal di kemudian hari. Hal ini tentunya dapat diperoleh dengan adanya metode analisa yang dapat membantu investor tersebut untuk memenuhi harapannya. Secara umum terdapat dua metode analisa yang dapat digunakan untuk menganalisa suatu saham emiten yaitu metode analisa teknikal dan metode analisa fundamental, metode analisa teknikal sendiri menurut (Rimawati, 2013) yaitu teknik untuk meramalkan arah perkembangan harga dan petunjuk pertukaran saham lainnya yang bergantung pada data pasar historis yang mempertimbangankan biaya instrumen, volume perdagangan dan jika mungkin minat atas instrumen. Metode analisis yang kedua adalah analisis fundamental, menurut Dardmaji \& Hendy (dalam Uyun, 2014) analisis fundamental adalah salah satu pendekatan untuk penilaian saham dengan memeriksa atau memperhatikan berbagai indikator yang diidentifikasi dengan kondisi makro ekonomi dan kondisi industri suatu perusahaan hingga berbagai indikator keuangan dan manajemen perusahaan.

Nilai wajar saham atau disebut juga nilai intrinsik saham adalah berapa harga saham tersebut sebenarnya layak dihargai atau suatu jumlah yang mencerminkan nilai saham tersebut sebenarnya. Menurut ( sebenarnya dari suatu perusahaan. Jadi seorang investor tentunya sangat perlu untuk mengetahui nilai wajar dari suatu saham sebelum melakukan transaksi membeli ataupun 
menjual saham agar meminimalisir kerugian yang terjadi ke depannya, karena membeli saham di saat harganya berada diatas nilai wajarnya.

Dalam menghitung nilai wajar suatu saham bisa menggunakan metode - metode menghitung valuasi saham diantaranya ada metode Price Earning Ratio (PER), Price to Book Value (PBV), dan Dividend Discount Model (DDM). Metode Price Earning Ratio (PER) sendiri adalah rasio menghitung valuasi saham dengan mengukur hubungan antara harga saham dengan laba per lembar saham, pendekatan PER juga mendasarkan diri pada model penentuan nilai saham pendekatan nilai sekarang. Selain PER ada juga yang menggunakan pendekatan nilai sekarang dengan menggunakan dividen sebagai komponen utama hitungnya yaitu Dividend Discount Model (DDM). Menurut (Tandelilin, 2017) DDM merupakan model untuk menentukan estimasi harga saham dengan mendiskontokan semua aliran dividen yang akan diterima di masa datang. Selanjutnya ada pendekatan dengan menggunakan model Price to Book Value (PBV)

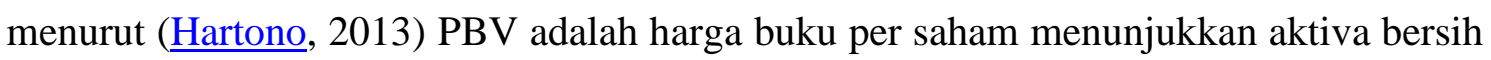
yang diklaim oleh investor dengan memiliki satu lembar.

Di BEI terdapat indeks yang mengukur semua kinerja harga saham yang terdaftar dan tercatat di bursa efek Indonesia yaitu Indeks Harga Saham Gabungan (IHSG). Sampai saat ini sudah terdapat 37 indeks dengan model dan kriteria masing - masing yang sudah di tentukan oleh pihak BEI dan analis saham. Selain IHSG ada indeks yang sangat populer dikalangan para investor yaitu indeks LQ45, karena ke populerannya indeks ini biasanya menjadi tolak ukur untuk seorang pemula di saham untuk membeli saham - saham yang terdaftar dalam indeks tersebut.

Indeks LQ45 sendiri adalah indeks yang mengukur kinerja dari 45 saham yang memiliki kapitalisasi pasar yang besar dan likuiditas tinggi serta di dukung dengan fundamental emiten yang baik. Adapun kriteria dari indeks LQ45 adalah Terdaftar di Bursa Efek Indonesia minimal 3 bulan, Memiliki kondisi keuangan yang baik serta prospek pertumbuhan dan nilai transaksi yang tinggi, masuk dalam 60 perusahaan teratas yang mempunyai kapitalisasi pasar yang besar dan nilai transaksi tertinggi di pasar reguler dalam jangka waktu 1 tahun terakhir. Adapun yang menjadi ruang lingkup pada penelitian ini adalah : (1) Variabel Independen adalah nilai wajar saham yang di hitung menggunakan ketiga metode yaitu DDM, PER, dan PBV. (2) Variabel dependen adalah harga pasar saham tahunan. (3) Objek penelitian yang digunakan dalam penelitian ini adalah 23 saham perusahaan yang masuk dalam kriteria sampel dan terdaftar di indeks LQ45. (4) Periode penelitian yang digunakan dalam penelitian ini adalah tahun $2017-2019$.

Menurut (Syari, 2018) menyatakan pasar modal adalah pasar yang digunakan untuk melakukan berbagai instrumen moneter jangka panjang yang dapat diperhualbelikan. Hal ini dapat meliputi obligasi, saham, reksa dana, instrumen derivatif dan instrumen lainnya.

investasi adalah suatu tindakan yang dilakukan seseorang untuk tidak melakukan hal - hal yang bersifat konsumtif saat ini untuk dibelikan aset yang 
produktif dengan harapan memperoleh keuntungan di kemudian hari (Yuliah, Triana, \& Lesmana, 2019).

Menurut (Azis, Mintarti, \& Maryam, 2015) Saham merupakan tanda penyertaan atau kepemilikan investor secara individu maupun intitusional atas investasi mereka atau sejumlah dana yang diinvestasikan pada suatu perusahaan.

Menurut ( suatu saham dan kemudian membandingkannya dengan harga pasar saat ini saham tersebut. Pedoman yang digunakan adalah : (1) Apabila nilai intrinsik > harga pasar saat ini, maka saham tersebut dinilai undervalued (harganya terlalu rendah), dan oleh karenanya saham tersebut seharusnya dibeli atau ditahan apabila saham tersebut sudah dimiliki. (2) Apabila nilai intrinsik < harga pasar saat ini, maka saham tersebut dinilai overvalued (harganya terlalu mahal), dan oleh karenanya saham tersebut seharusnya dijual. (3) Apabila nilai intrinsik = harga pasar saat ini, maka saham tersebut dinilai wajar harganya dan berada dalam kondisi keseimbangan.

Metode Dividend Discount Model atau juga bisa disebut model diskonto dividen adalah salah satu metode menghitung valuasi nilai atau intrinsik saham dengan menggunakan dividen sebagai komponen utama hitungnya. Metode Dividend Discount Model (DDM) dengan Model pertumbuhan konstan adalah metode yang menyatakan bahwa perusahaan nantinya akan selalu memberikan dividen yang secara konstan atau terus - menerus bertumbuh tiap tahunnya. Adapun rumus dari model ini dapat diketahui sebagai berikut :

$$
\widehat{\mathrm{P}}_{0}=\frac{\mathrm{D}_{1}}{\mathrm{k}-\mathrm{g}}
$$

Sumber : (Tandelilin, 2017)

Menurut (May, 2011) Price Earning Ratio (PER) adalah rasio harga saham di bursa dengan laba bersih per saham. Metode PER menggambarkan perbandingan antara harga saham terhadap earning perusahaan. Dari PER juga dapat diketahui berapa rupiah harga yang harus dibayar investor untuk mendapatkan setiap Rp.1 earning perusahaan. Adapun rumus hitung untuk mengetahui Price Earning Ratio adalah sebagai berikut:

$$
\widehat{\mathrm{P}} / \mathrm{E}_{1}=\frac{\mathrm{D}_{1} / \mathrm{E}_{1}}{\mathrm{k}-\mathrm{g}}
$$

Sumber : (Tandelilin, 2017)

Menurut (May, 2011) Price to Book Value (PBV) adalah angka rasio yang menjelaskan seberapa kali seorang investor bersedia membayar sebuah saham untuk setiap nilai buku per sahamnya. Secara teoritis harga pasar suatu saham harus mencerminkan nilai bukunya. Oleh karena itu antara nilai buku per lembarnya dengan harga saham dapat juga menjadi opsi untuk menentukan nilai suatu saham. Adapun rumus hitung untuk mengetahui Price to Book Value (PBV) adalah sebagai berikut:

- Menghitung BVS

$$
\begin{aligned}
& \text { BVS }=\frac{\text { Total Ekuitas }}{\text { Jumlah Saham Beredar }} \\
& \text { - } \quad \text { Menghitung PBV ratio }
\end{aligned}
$$


PBV ratio $=\frac{\text { Harga Pasar Saham }}{\text { BVS }}$

Sumber : (Fahmi, 2017)

\section{Metode Penelitian}

Penelitian ini merupakan penelitian yang menggunakan metode deskriptif dengan pendekatan kuantitatif. Pada penelitian ini yang membedakan dengan penelitian terdahulu adalah dari pemilihan variabel hitung valuasinya yang dimana masih sedikit ditemukan yang menggunakan metode DDM, PER, \& PBV secara bersama - sama. Selain itu yang juga menjadi pembeda dengan peneliti terdahulu adalah penelitian ini menggunakan indeks sebagai studi kasus sampel perusahaanya, yang dimana masih jarang digunakan karena peneliti terdahulu kebanyakan menggunakan sektor sebagai studi kasus penelitiannya. Dalam penelitian ini penulis menggunakan teknik purposive sampling. Purposive sampling adalah teknik penentuan sampel berdasarkan pertimbangan pertimbangan tertentu. Adapun kriteria - kriteria yang menjadi pemilihan sampel pada penelitian ini adalah sebagai berikut : (1) Perusahaan selalu masuk dan tidak pernah keluar dari indeks LQ45 serta terdaftar di BEI selama masa periode penelitian 2017 2019. (2) Perusahaan yang terus membagikan dividen secara konsisten tiap tahunnya dalam kurun waktu penelitian periode 2017 - 2019. (3) Perusahaan yang mempunyai laporan keuangan yang lengkap dalam kurun waktu penelitian tahun 2017 - 2019. (4) Memiliki nilai $\mathrm{k}$ (return yang diisyaratkan investor) yang lebih besar dari nilai $\mathrm{g}$ (pertumbuhan dividen). Berdasarkan kriteria - kriteria tersebut di peroleh 23 perusahaan yang dapat memenuhi kriteria dan dapat dijadikan sampel penelitian. Daftar emiten yang dapat dijadikan sampel adalah sebagai berikut: 
Tabel 1. Daftar Sampel Penelitian

\begin{tabular}{ccl}
\hline NO & KODE & \multicolumn{1}{c}{ EMITEN } \\
\hline 1 & ADRO & PT. Adaro Energy Tbk. \\
\hline 2 & AKRA & PT. AKR Corporindo Tbk. \\
\hline 3 & ASII & PT. Astra International Tbk. \\
\hline 4 & BBCA & PT. Bank Central Asia Tbk. \\
\hline 5 & BBNI & PT. Bank Negara Indonesia (Persero) Tbk. \\
\hline 6 & BBRI & PT. Bank Rakyat Indonesia (Persero) Tbk. \\
\hline 7 & BBTN & PT. Bank Tabungan Negara (Persero) Tbk. \\
\hline 8 & BMRI & PT. Bank Mandiri (Persero) Tbk. \\
\hline 9 & HMSP & PT. Hanjaya Mandala Sampoerna Tbk. \\
\hline 10 & ICBP & PT. Indofood CBP Sukses Makmur Tbk. \\
\hline 11 & INDF & PT. Indofood Sukses Makmur Tbk. \\
\hline 12 & INTP & PT. Indocement Tunggal Prakarsa Tbk. \\
\hline 13 & JSMR & PT. Jasa Marga (Persero) Tbk. \\
\hline 14 & KLBF & PT. Kalbe Farma Tbk. \\
\hline 15 & PGAS & PT. Perusahaan Gas Negara (Persero) Tbk. \\
\hline 16 & PTBA & PT. Bukit Asam Tbk. \\
\hline 17 & PTPP & PT. Pembangunan Perumahan (Persero) Tbk. \\
\hline 18 & SCMA & PT. Surya Citra Media Tbk. \\
\hline 19 & SMGR & PT. Semen Indonesia (Persero) Tbk. \\
\hline 20 & SRIL & PT. Sri Rejeki Isman Tbk. \\
\hline 21 & TLKM & PT. Telkom Indonesia (Persero) Tbk. \\
\hline 22 & WIKA & PT. Wijaya Karya (Persero) Tbk. \\
\hline 23 & WSKT & PT. Waskita Karya (Persero) Tbk. \\
\hline & & Sum Data
\end{tabular}

Sumber : Data diolah (2021)

\section{Melakukan Analisa Perbandingan Metode}

Analisa perbandingan metode penilaian harga saham ini dilakukan untuk mendapati dari ketiga pendekatan model DDM, PER, \& PBV pendekatan penilaian harga saham mana yang tingkat akurasinya paling tepat. Untuk dapat mengetahui metode mana yang paling akurat dari ketiga model tersebut dapat menggunakan Uji RMSE (Root Mean Squared Error). Uji RMSE adalah uji pengukuran beda antara nilai yang diprediksi dengan nilai yang diketahui. Dalam penelitian ini nantinya yang menjadi nilai yang diketahui adalah harga pasar saham tahunan, sedangkan untuk nilai yang diprediksi adalah nilai intrinsik yang diperoleh dari ketiga metode DDM, PER, \& PBV. Adapun rumus untuk melakukan Uji RMSE adalah sebagai berikut :

$$
\mathrm{RMSE}=\frac{\sum_{\mathrm{i}=1}^{\mathrm{n}}\left(\mathrm{X}_{\mathrm{i}}-\mathrm{Y}_{\mathrm{i}}\right)^{2}}{\mathrm{n}}
$$

Sumber : (Chai \& Draxler, 2014) 


\section{Hasil dan Pembahasan}

Tabel 2. Membandingkan Nilai Wajar Emiten Indeks LQ45 dan Pengambilan Keputusan Investasi yang tepat dengan Metode DDM, PER, \& PBV untuk Tahun 2017

\begin{tabular}{|c|c|c|c|c|c|c|c|}
\hline \multirow{3}{*}{$\begin{array}{c}\text { Kode } \\
\text { Saham }\end{array}$} & \multirow{3}{*}{$\begin{array}{c}\text { Harga } \\
\text { Pasar (Rp) }\end{array}$} & \multirow{2}{*}{\multicolumn{2}{|c|}{ DDM }} & \multirow{2}{*}{\multicolumn{2}{|c|}{ PER }} & \multirow{2}{*}{\multicolumn{2}{|c|}{ PBV }} \\
\hline & & & & & & & \\
\hline & & $\begin{array}{c}\text { Nilai } \\
\text { Wajar }\end{array}$ & Keterangan & $\begin{array}{c}\text { Nilai } \\
\text { Wajar }\end{array}$ & Keterangan & $\begin{array}{c}\text { Nilai } \\
\text { Wajar }\end{array}$ & Keterangan \\
\hline ADRO & 1.860 & $1.975,68$ & Undervalued & $3.443,88$ & Undervalued & $2.894,19$ & Undervalued \\
\hline AKRA & 6.350 & $6.657,38$ & Undervalued & $9.367,3$ & Undervalued & $2.253,85$ & Overvalued \\
\hline ASII & 8.300 & $9.044,37$ & Undervalued & $7.994,51$ & Overvalued & $5.097,23$ & Overvalued \\
\hline BBCA & 21.900 & $24.734,51$ & Undervalued & 27.877,71 & Undervalued & $8.154,3$ & Overvalued \\
\hline BBNI & 9.900 & $10.778,33$ & Undervalued & $10.778,34$ & Undervalued & $8.278,44$ & Overvalued \\
\hline BBRI & 3.640 & $3.984,89$ & Undervalued & $4.483,13$ & Undervalued & 2.083,99 & Overvalued \\
\hline BBTN & 3.570 & $3.969,93$ & Undervalued & $3.970,21$ & Undervalued & $3.129,84$ & Overvalued \\
\hline BMRI & 8.000 & $8.554,25$ & Undervalued & $8.554,41$ & Undervalued & $5.573,77$ & Overvalued \\
\hline HMSP & 4.730 & $4.755,79$ & Undervalued & $4.772,47$ & Undervalued & $1.504,47$ & Overvalued \\
\hline ICBP & 8.900 & $9.678,41$ & Undervalued & $9.655,15$ & Undervalued & $10 . .143,09$ & Undervalued \\
\hline INDF & 7.625 & $8.044,15$ & Undervalued & $8.065,97$ & Undervalued & $30.992,14$ & Undervalued \\
\hline INTP & 21.950 & $21.311,01$ & Overvalued & $33.416,56$ & Undervalued & $21.279,62$ & Overvalued \\
\hline JSMR & 6.400 & $6.984,57$ & Undervalued & $4.656,56$ & Overvalued & $3.389,65$ & Overvalued \\
\hline KLBF & 1.690 & $1.843,2$ & Undervalued & $\mathbf{2 . 0 0 3 , 8 7}$ & Undervalued & $1.499,83$ & Overvalued \\
\hline PGAS & 1.750 & $1.798,94$ & Undervalued & $1.594,73$ & Overvalued & $3.241,58$ & Undervalued \\
\hline PTBA & 2.460 & $2.606,13$ & Undervalued & $6.515,26$ & Undervalued & $2.000,41$ & Overvalued \\
\hline PTPP & 2.640 & $2.894,86$ & Undervalued & $1.929,99$ & Overvalued & $5.352,73$ & Undervalued \\
\hline SCMA & 2.480 & $2.610,51$ & Undervalued & 3.023,39 & Undervalued & 605,59 & Overvalued \\
\hline SMGR & 9.900 & $102.97,54$ & Undervalued & $10.298,59$ & Undervalued & $16.370,28$ & Undervalued \\
\hline SRIL & 380 & 437,82 & Undervalued & $1.010,23$ & Undervalued & 207,95 & Overvalued \\
\hline TLKM & 4.440 & $4.746,31$ & Undervalued & $4.453,66$ & Undervalued & $1.624,1$ & Overvalued \\
\hline WIKA & 1.550 & $1.665,17$ & Undervalued & $1.110,2$ & Overvalued & $3.800,69$ & Undervalued \\
\hline WSKT & 2.210 & $2.536,19$ & Undervalued & $1.690,49$ & Overvalued & $3.905,98$ & Undervalued \\
\hline
\end{tabular}

Sumber : Data diolah (2021)

Pada tabel 2, setelah membandingkan antara nilai wajar dengan harga saham yang terbentuk maka dapat diketahui, penghitungan nilai wajar dengan metode DDM pada 
tahun 2017 diperoleh hasil 22 saham emiten ada pada kondisi undervalued jadi keputusan tepat yang dapat diambil adalah membeli, selain itu terdapat 1 saham yang ada pada keadaan overvalued yaitu INTP maka keputusan tepat yang dapat dilakukan adalah menjual. Berdasarkan penghitungan nilai wajar dengan metode PER pada tahun 2017 diperoleh hasil 17 saham emiten ada pada keadaan undervalued maka keputusan tepat yang diambil adalah membeli, serta terdapat 6 saham yang ada pada keadaan overvalued yaitu ASII, JSMR, PGAS, PTPP, WIKA, \& WSKT maka keputusan investasi yang tepat adalah menjual. Berdasarkan perhitungan nilai wajar menggunakan metode PBV pada tahun 2017 diperoleh hasil 15 saham perusahaan berada pada kondisi overvalued dan keputusan tepat yang dapat diambil adalah melakukan aksi jual, serta terdapat 8 saham yang berada dalam keadaan undervalued yaitu ADRO, ICBP, INDF, PGAS, PTPP, SMGR, WIKA, \& WSKT maka keputusan investasi yang diambil adalah membeli.

Tabel 3. Membandingkan Nilai Wajar Emiten Indeks LQ45 dan Pengambilan Keputusan Investasi yang tepat dengan Metode DDM, PER, \& PBV untuk Tahun 2018

\begin{tabular}{|c|c|c|c|c|c|c|c|}
\hline \multirow{3}{*}{$\begin{array}{c}\text { Kode } \\
\text { Saham }\end{array}$} & \multirow{3}{*}{$\begin{array}{c}\text { Harga } \\
\text { Pasar (Rp) }\end{array}$} & \multirow{2}{*}{\multicolumn{2}{|c|}{ DDM }} & \multirow{2}{*}{\multicolumn{2}{|c|}{ PER }} & \multirow{2}{*}{\multicolumn{2}{|c|}{ PBV }} \\
\hline & & & & & & & \\
\hline & & $\begin{array}{l}\text { Nilai } \\
\text { Wajar }\end{array}$ & Keterangan & $\begin{array}{l}\text { Nilai } \\
\text { Wajar }\end{array}$ & Keterangan & $\begin{array}{l}\text { Nilai } \\
\text { Wajar }\end{array}$ & Keterangan \\
\hline ADRO & 1.215 & $1.285,83$ & Undervalued & $1.160,83$ & Overvalued & $5.535,93$ & Undervalued \\
\hline AKRA & 4.290 & $4.575,73$ & Undervalued & $4.019,85$ & Overvalued & $3.412,21$ & Overvalued \\
\hline ASII & 8.225 & $8.999,98$ & Undervalued & $9.075,24$ & Undervalued & $5.426,83$ & Overvalued \\
\hline BBCA & 26.000 & 28.993,07 & Undervalued & $34.852,03$ & Undervalued & $10.155,86$ & Overvalued \\
\hline BBNI & 8.800 & $9.702,19$ & Undervalued & $6.930,02$ & Overvalued & $9.765,67$ & Undervalued \\
\hline BBRI & 3.660 & $3.599,01$ & Overvalued & $8.679,47$ & Undervalued & $2.478,43$ & Overvalued \\
\hline BBTN & 2.540 & $2.779,34$ & Undervalued & $2.779,15$ & Undervalued & $3.714,51$ & Undervalued \\
\hline BMRI & 7.375 & $7.942,09$ & Undervalued & 7.942 & Undervalued & $6.539,67$ & Overvalued \\
\hline HMSP & 3.710 & $3.700,11$ & Overvalued & $3.782,45$ & Undervalued & $1.453,02$ & Overvalued \\
\hline ICBP & 10.450 & $11.528,94$ & Undervalued & $11.514,12$ & Undervalued & $10.942,81$ & Undervalued \\
\hline INDF & 7.450 & $7.822,22$ & Undervalued & 7.793,65 & Undervalued & $31.949,75$ & Undervalued \\
\hline INTP & 18.450 & $17.867,34$ & Overvalued & $22.643,59$ & Undervalued & $15.770,25$ & Overvalued \\
\hline JSMR & 4.280 & $4.646,67$ & Undervalued & $3.484,84$ & Overvalued & $3.757,11$ & Overvalued \\
\hline KLBF & 1.520 & $1.645,13$ & Undervalued & $1.673,73$ & Undervalued & $2.133,87$ & Undervalued \\
\hline PGAS & 2.120 & $2.286,31$ & Undervalued & $1.802,36$ & Overvalued & $4.052,78$ & Undervalued \\
\hline PTBA & 4.300 & $4.599,41$ & Undervalued & $4.369,83$ & Undervalued & $3.996,58$ & Overvalued \\
\hline PTPP & 1.805 & $1.978,44$ & Undervalued & $1.978,2$ & Undervalued & $6.631,61$ & Undervalued \\
\hline
\end{tabular}


Gideon Toman ${ }^{1}$ Sri Muljaningsih ${ }^{2}$ Kiki Asmara ${ }^{3}$

\begin{tabular}{cccccccc}
\hline SCMA & 1.870 & $2.139,1$ & Undervalued & $1.304,33$ & Overvalued & 666,59 & Overvalued \\
\hline SMGR & 11.500 & $12.150,99$ & Undervalued & $12.149,5$ & Undervalued & $13.797,6$ & Undervalued \\
\hline SRIL & 358 & 413,97 & Undervalued & 116,86 & Overvalued & 69,74 & Overvalued \\
\hline TLKM & 3.750 & $3.836,31$ & Undervalued & $4.523,96$ & Undervalued & $1.669,66$ & Overvalued \\
\hline WIKA & 1.655 & $1.814,43$ & Undervalued & $1.814,25$ & Undervalued & $4.836,43$ & Undervalued \\
\hline WSKT & 1.680 & $1.881,45$ & Undervalued & $2.352,06$ & Undervalued & $5.362,91$ & Undervalued \\
\hline
\end{tabular}

Sumber : Data diolah (2021)

Pada tabel 3, setelah membandingkan antara nilai wajar dengan harga pasar saham yang terbentuk maka dapat diketahui, penghitungan nilai wajar dengan metode DDM pada tahun 2018 diperoleh hasil 20 saham perusahaan ada pada kondisi undervalued dan keputusan tepat yang dapat diambil adalah beli, serta terdapat 3 saham yang ada pada keadaan overvalued yaitu BBRI, HMSP, \& INTP maka keputusan investasi yang diambil adalah menjual. Berdasarkan penghitungan nilai wajar dengan metode PER Pada tahun 2018 diperoleh hasil 16 saham perusahaan ada pada kondisi undervalued dan keputusan tepat yang dapat diambil adalah membeli, serta terdapat 7 saham yang ada pada keadaan overvalued yaitu ADRO, AKRA, BBNI, JSMR, PGAS, SCMA, \& SRIL maka keputusan investasi yang diambil adalah menjual. Berdasarkan perhitungan nilai wajar menggunakan metode PBV pada tahun 2018 diperoleh hasil 12 saham ada pada kondisi overvalued jadi keputusan tepat yang diambil adalah jual, serta terdapat 11 saham yang ada pada keadaan undervalued maka keputusan yaang diambil adalah membeli.

Tabel 4. Membandingkan Nilai Wajar Emiten Indeks LQ45 dan Pengambilan Keputusan Investasi yang tepat dengan Metode DDM, PER, \& PBV untuk Tahun 2019

\begin{tabular}{|c|c|c|c|c|c|c|c|}
\hline \multirow{3}{*}{$\begin{array}{c}\text { Kode } \\
\text { Saham }\end{array}$} & \multirow{3}{*}{$\begin{array}{c}\text { Harga } \\
\text { Pasar (Rp) }\end{array}$} & \multirow{2}{*}{\multicolumn{2}{|c|}{ DDM }} & \multirow{2}{*}{\multicolumn{2}{|c|}{ PER }} & \multirow{2}{*}{\multicolumn{2}{|c|}{ PBV }} \\
\hline & & & & & & & \\
\hline & & $\begin{array}{c}\text { Nilai } \\
\text { Wajar }\end{array}$ & Keterangan & $\begin{array}{c}\text { Nilai } \\
\text { Wajar }\end{array}$ & Keterangan & $\begin{array}{c}\text { Nilai } \\
\text { Wajar }\end{array}$ & Keterangan \\
\hline ADRO & 1.555 & $1.618,85$ & Undervalued & $2.127,98$ & Undervalued & $2.218,93$ & Undervalued \\
\hline AKRA & 3.950 & 4.055,97 & Undervalued & $4.263,47$ & Undervalued & $4.839,47$ & Undervalued \\
\hline ASII & 6.925 & $7.518,04$ & Undervalued & $7.501,69$ & Undervalued & $5.074,64$ & Overvalued \\
\hline BBCA & 33.425 & $36.282,63$ & Undervalued & $53.607,63$ & Undervalued & $18.264,42$ & Overvalued \\
\hline BBNI & 7.850 & $8.580,65$ & Undervalued & $8.580,65$ & Undervalued & $17.333,29$ & Undervalued \\
\hline BBRI & 4.400 & $4.687,23$ & Undervalued & $2.584,32$ & Overvalued & $4.333,23$ & Overvalued \\
\hline BBTN & 2.120 & $2.136,79$ & Undervalued & $1.070,55$ & Overvalued & $5.820,31$ & Undervalued \\
\hline BMRI & 7.675 & $8.092,9$ & Undervalued & $10.790,45$ & Undervalued & $1.1467,03$ & Undervalued \\
\hline
\end{tabular}


Penilaian Harga Wajar Saham pada Emiten yang Terdaftar di Indeks LQ45 Periode $2017-2019$

\begin{tabular}{|c|c|c|c|c|c|c|c|}
\hline HMSP & 2.100 & $2.087,44$ & Overvalued & $2.105,17$ & Undervalued & 889,54 & Overvalued \\
\hline ICBP & 11.150 & $12.275,79$ & Undervalued & $12.291,23$ & Undervalued & $10.131,54$ & Overvalued \\
\hline INDF & 7.925 & $\mathbf{8 . 3 5 8 , 8 7}$ & Undervalued & $\mathbf{8 . 3 5 7 , 8 5}$ & Undervalued & $27.346,83$ & Undervalued \\
\hline INTP & 19.025 & $19.020,84$ & Overvalued & $10.796,54$ & Overvalued & $10.595,811$ & Overvalued \\
\hline JSMR & 5.175 & $5.614,6$ & Undervalued & $1.871,01$ & Overvalued & $4.632,11$ & Overvalued \\
\hline KLBF & 1.620 & $1.774,09$ & Undervalued & $1.337,64$ & Overvalued & $1.119,03$ & Overvalued \\
\hline PGAS & 2.170 & $2.164,5$ & Overvalued & $7.450,87$ & Undervalued & 301,87 & Overvalued \\
\hline PTBA & 2.660 & $2.702,53$ & Undervalued & $3.216,95$ & Undervalued & $2.014,87$ & Overvalued \\
\hline PTPP & 1.585 & $1.670,55$ & Undervalued & $1.883,83$ & Undervalued & $4.052,15$ & Undervalued \\
\hline SCMA & 1.410 & $1.586,82$ & Undervalued & $1.090,58$ & Overvalued & $1.187,95$ & Overvalued \\
\hline SMGR & 12.000 & $12.756,24$ & Undervalued & $3.189,18$ & Overvalued & $9.656,44$ & Overvalued \\
\hline SRIL & 260 & 297,82 & Undervalued & 109,73 & Overvalued & 606,47 & Undervalued \\
\hline TLKM & 3.970 & $4.140,26$ & Undervalued & $3.762,19$ & Overvalued & $4.474,01$ & Undervalued \\
\hline WIKA & 1.990 & $2.207,14$ & Undervalued & $2.205,97$ & Undervalued & $3.106,23$ & Undervalued \\
\hline WSKT & 1.485 & $1.534,78$ & Undervalued & 306,45 & Overvalued & $3.110,49$ & Undervalued \\
\hline
\end{tabular}

Sumber : Data diolah (2021)

Pada tabel 4, setelah membandingkan antara nilai wajar dengan harga pasar saham yang terbentuk maka dapat diketahui, penghitungan nilai wajar dengan metode DDM pada tahun 2019 diperoleh hasil 20 saham perusahaan ada pada kondisi undervalued dan keputusan tepat yang dapat diambil adalah melakukan aksi beli, serta terdapat 3 saham yang ada pada keadaan overvalued yaitu HMSP, INTP, \& PGAS maka keputusan investasi yang diambil adalah melakukan aksi jual. Berdasarkan penghitungan nilai wajar dengan metode PER pada tahun 2019 diperoleh hasil 13 saham berada dalam kondisi undervalued yaitu ADRO, AKRA, ASII, BBCA, BBNI, BMRI, HMSP, ICBP, INDF, PGAS, PTBA, PTPP, \& WIKA maka keputusan tepat yang dapat diambil adalah beli, serta terdapat 10 saham yang ada pada keadaan overvalued yaitu BBRI, BBTN, INTP, JSMR, KLBF, SCMA, SMGR, SRIL, TLKM, \& WSKT maka keputusan investasi yang diambil adalah menjual. Berdasarkan perhitungan nilai wajar menggunakan metode PBV pada tahun 2019 diperoleh hasil 12 saham berada dalam kondisi overvalued yaitu ASII, BBCA, BBRI, HMSP, ICBP, INTP, JSMR, KLBF, PGAS, PTBA, SCMA, \& SMGR maka keputusan investasi yang diambil adalah menjual, serta terdapat 11 saham yang ada pada keadaan undervalued yaitu ADRO, AKRA, BBNI, BBTN, BMRI, INDF, PTPP, SRIL, TLKM, WIKA, \& WSKT maka keputusaan investasi yang diambil adalah membeli. 
Gideon Toman ${ }^{1}$ Sri Muljaningsih ${ }^{2}$ Kiki Asmara ${ }^{3}$

Tabel 5. Nilai Root Mean Square Error

\begin{tabular}{ccccc}
\hline \multirow{2}{*}{ NO } & \multirow{2}{*}{ Pendekatan } & \multicolumn{3}{c}{ RMSE (Rp) } \\
\cline { 3 - 5 } & & $\mathbf{2 0 1 7}$ & $\mathbf{2 0 1 8}$ & $\mathbf{2 0 1 9}$ \\
\hline 1 & DDM & 725.03 & 762 & 712.91 \\
\hline 2 & PER & 2971.34 & 2375.03 & 5151.82 \\
\hline 3 & PBV & 6138.88 & 6454.07 & 5984.08 \\
\hline \multicolumn{4}{c}{ Sumber : Data diolah $(2021)$}
\end{tabular}

Pada tabel 5, setelah melakukan uji RMSE pada metode menghitung nilai wajar DDM, PER, \& PBV, dapat diketahui nilai RMSE yang paling kecil secara berurutan pada tahun 2017 - 2019 dimiliki oleh metode DDM yaitu 725,03, 762, dan 712,91. Sedangkan nilai RMSE terbesar pada tahun 2017 - 2019 dimiliki oleh pendekatan PBV yaitu sebesar 6138,88, 6454,07, dan 5984,08. Dari perhitungan uji RMSE dapat disimpulkan bahwa perhitungan nilai wajar dengan menggunakan metode DDM menjadi metode yang paling akurat karena memiliki nilai RMSE terkecil pada tahun 2017 - 2019 diikuti oleh metode PER lalu metode PBV. Hasil penelitian ini di dukung oleh penelitian sebelumnya yang dilakukan oleh (Hasanah dan Rusliati 2017) serta (Sari dan Hermastuti 2020) yang menyatakan bahwa pendekatan yang paling akurat dengan uji RMSE untuk mengetahui nilai wajar saham adalah pendekatan DDM.

\section{Kesimpulan}

Berdasarkan hasil hitung harga wajar menggunakan DDM, PER, dan PBV, pengambilan keputusan investasi yang tepat adalah dengan membeli saham - saham emiten berikut, diantaranya ADRO, BBNI, BBTN, BMRI, ICBP, INDF, PTPP, SMGR, WIKA, \& WSKT. Hal ini dikarenakan 10 saham perusahaan tersebut rata - rata harganya dinilai undervalued atau murah.

Hasil dari melakukan analisa perbandingan model penilaian saham menunjukkan metode Dividend Discount Model (DDM) merupakan model penilaian saham dengan penyimpangan paling kecil, dengan nilai RMSE pada tahun 2017 - 2019 secara berurutan sebesar 725,03, 762, dan 712,91. Artinya pedekatan Dividend Discount Model (DDM) adalah model penilaian saham yang paling akurat. 
Penilaian Harga Wajar Saham pada Emiten yang Terdaftar di Indeks LQ45 Periode $2017-2019$

\section{Bibliografi}

Azis, Musdalifah, Mintarti, Sri, \& Maryam, Nadir. (2015). Manajemen Investasi Fundamental, Teknikal, Perilaku Investor \& Return Saham. Yogyakarta: Deepublish.

Chai, T., \& Draxler, R. R. (2014). Root mean square error (RMSE) or mean absolute error (MAE)? -Arguments against avoiding RMSE in the literature. Geoscientific Model Development, 7(3), 1247-1250. https://doi.org/10.5194/gmd-7-1247-2014

Fahmi, Irham. (2017). Pengantar Pasar Modal. Bandung: Alfabeta.

Hartono, Jogiyanto. (2013). Teori Portofolio dan Analisis Investasi. Yogyakarta: BPFE.

Hasanah, Resti, \& Rusliati, Ellen. (2017). Harga Saham Dengan Metode Dividend Discount Model Dan Price To Book Value. Jurnal Riset Bisnis Dan Manajemen, 10(2), 1. https://doi.org/10.23969/jrbm.v10i2.446

Husnan, Suad. (2015). Dasar - Dasar Teori Portofolio \& Analisis Sekuritas (5th ed.). Yogyakarta: UPP STIM YKPM.

May, Ellen. (2011). Smart Traders not Gamblers. Jakarta: PT Gramedia Pustaka Utama.

Rimawati, Elistya. (2013). ISSN : 1693-1173 Analisa Fundamental Dan Analisa Teknikal Pada Rencana Investasi Pasar Modal Elistya Rimawati. Jurnal Ilmiah SINUS, 2132. http://dx.doi.org/10.30646/sinus.v11i2.118

Sari, Dewi Ratna, \& Hermastuti, Pristina. (2020). Valuasi Harga Wajar Saham Menggunakan Metode Dividend Discount Model Dan Price To Book Value Ratio ( Studi Empiris pada Perusahaan Sub Sektor Property dan Real Estate yang Terdaftar di Bursa Efek Indonesia pada Tahun 2016-2019).

Syari, Astria Semaradilla. (2018). Evaluasi Kondisi Saham Melalui Analisis Fundamental Dengan Metode Dividend Discount Model ( Ddm ) Terhadap Keputusan Investasi Pada Perusahaan Sub Sektor Pulp and Paper Yang. 3(Ddm), 1-13.

Tandelilin, Eduardus. (2017). Pasar Modal Manajemen Portofolio \& Investasi. Yogyakarta: Kanisius.

Uyun, N. (2014). Penerapan Analisis Fundamental Dengan Pendekatan Price Earning Ratio (PER) Sebagai Dasar Penilaian Kewajaran Harga Saham Dalam Pengambilan Keputusan Investasi (Studi Pada Subsektor Konstruksi Bangunan yang Terdaftar Di Bursa Efek Indonesia Tahun 2010-2012. Jurnal Administrasi Bisnis S1 Universitas Brawijaya, 12(1), 83150.

Yuliah, Triana, Leni, \& Lesmana, Ihwan Satria. (2019). Analisis Nilai Saham Dengan Dividend Discount Model (DDM) (Studi kasus Perusahaan Tekstil Dan Garmen Yang Terdaftar Di Bursa Efek Indonesia Tahun 2018). Jurnal Manajemen STIE 
Gideon Toman ${ }^{1}$ Sri Muljaningsih ${ }^{2}$ Kiki Asmara ${ }^{3}$

Muhammadiyah Palopo, 5(2), 9-13. http://dx.doi.org/10.35906/jm001.v5i2.360 